International Journal of Environment, Agriculture and Biotechnology
Vol-7, Issue-1; Jan-Feb, 2022
JUEAB
Journal Home Page Available: https://ijeab.com/
Journal DOI: $10.22161 /$ ijeab

Peer Reviewed

\title{
Evaluation of Orange-Fleshed Sweet Potato (OFSP) Genotypes for Yield, Dry Matter, Starch and Beta- Carotene Content in Uyo, Southeastern Nigeria
}

\author{
Gamaliel I. Harry, Joseph I. Ulasi*
}

Department of Crop Science, Faculty of Agriculture, University of Uyo, P.M.B 1017, Uyo, Akwa, Ibom State, Nigeria *Corresponding author's details: Joseph I. Ulasi; ifeanyijoseph@uniuyo.edu.ng

Received: 30 Nov 2021; Received in revised form: 21 Jan 2022; Accepted: 03 Feb 2022; Available online: 11 Feb 2022 (C)2022 The Author(s). Published by Infogain Publication. This is an open access article under the CC BY license (https://creativecommons.org/licenses/by/4.0/).

\begin{abstract}
Six orange-fleshed sweetpotato genotypes, namely, Naspot-12, Umuspo-1, Lourdes, Erica, Delvia and umuspo-3, sourced from National Root Crops Research Institute, Umudike were evaluated for fresh storage root yield, dry matter, starch and Beta-carotene content in 2020 and 2021 cropping seasons at the Teaching and Research Farm of the University of Uyo. The experiment was laid in a randomized complete block design with three replications. Analysis of variance, correlation and principal component analysis were performed for yield and yield related traits while standard procedure was followed to determine dry matter, starch and beta-carotene content. In this study, results from the analysis of variance showed that the six orange-fleshed sweetpotato genotypes differed significantly $(P \leq 0.05)$ in number of marketable roots, weight of marketable roots and fresh storage roots yield. Umuspo-3 produced the highest storage root yield (28.78t/ha, 27.55t/ha) in 2020 and 2021 cropping seasons, respectively. The result of the correlation analysis also revealed that number of marketable roots and weight of marketable were highly significantly and positively $(P \leq 0.01)$ correlated with fresh root yield. Principal component analysis $(P C A)$ had two main principal components explaining $70.25 \%$ of the total variation with number of marketable roots, weight of marketable tuber and storage root yield contributing the most to the first PCA. Umuspo-3 recorded the highest dry matter content of $42.78 \%$. Lourdes had the highest starch content, $65.23 \mathrm{mg} 100 \mathrm{~g}^{-1}$ while Umuspo3 had the lowest starch content, $24.55 \mathrm{mg}^{100^{-1}}$. Beta-carotene content of the six OFSP genotypes ranged from 1.03mg/100g FW to 9.19mg/100g FW. Umuspo-3 recorded a Beta-carotene content of $9.19 \mathrm{mg} / 100 \mathrm{~g}$ FW.Umuspo-3 genotype could be recommended for cultivation in Uyo agro-ecology for high yield and as an excellent source of beta-carotene, it could be consumed to ameliorate vitamin A deficiency in children and pregnancy women within the State and its environs.
\end{abstract}

Keywords-Beta-carotene, Dry matter, Genotypes, Orange-fleshed sweetpotato, Vitamin A.

\section{INTRODUCTION}

Sweetpotato (Ipomoea batatas (L.) Lam) is a tuber crop, dicotyledonous in nature and belongs to the morning glory family, Convolvulaceae and it is an important stable crop consumed in many developing countries in Sub-Saharan Africa (Thottappilly and Loebenstein, 2009). Sweetpotato is cultivated the different continents of the world on approximately 8.21 million hectare with an estimated annual yield of 104.02 million tonnes (FAOSTAT, 2015).
The nutritional content of sweetpotato is enriched with a protein above that of other tuber crops, namely; cassava and yam as well as carotenes, which is a useful source of vitamin A (Mukhtar et al., 2010).

Sweetpotato is grown in all agro-ecologies and across all states in Nigeria and is the seventh most important food crop after wheat, rice, maize, potato, barley and cassava (FAO, 2015). Despite the high production rate in Nigeria, yield has 
remained low with estimated average storage root production of 3.0 tons/ha (FAOSTAT, 2015).

Fresh storage root of sweetpotato has low glycemic index, considering the slow rate of digestion of its complex carbohydrate and its lower rate of absorption of sugars into the blood stream. It is therefore, a suitable source of food for the diabetics (Willcox et al., 2009). Sweetpotato has numerous industrial uses (Lin et al., 2007). It is a common source of industrial raw materials such as starch and alcohol, yielding $30-50 \%$ higher starch compared to rice, corn and wheat sources under same environmental conditions (Rahman et al., 2003). 70 percent of the dry weight of sweetpotato is constituted by the starch content and high dry matter content serves as a significant characteristic of a good sweetpotato variety (Mwanga et al., 2007). Starch contributes to the textural properties of foods products and it is widely used for food and industrial applications as thickener, colloidal stabilizer, and gelling, bulking and water retention agent (Singh et al., 2008).

Highly nutritious Orange-Fleshed Sweet Potato (OFSP) varieties are enriched with vitamin A but has minimal dry matter content (Tumwegamire et al. 2011). Beta carotene is a major source of vitamin A, which is remedy for vitamin A deficiency (Omiat et al., 2005). In developing countries, including Nigeria, vitamin A deficiency is a prevalent condition with adverse health implications on young children. A major improvement of the sweetpotato breeding is the development of the OFSP varieties are enriched significant quantity of beta carotene that the human body system utilizes to produce vitamin A (Wariboko and Ogidi, 2014). It is reported that regular intake of one hundred grams of orange-fleshed varieties containing about 3 $\mathrm{mg} / 100 \mathrm{~g} \beta$-carotene on a fresh weight basis is adequate to meet the recommended daily allowance of vitamin $\mathrm{A}$, and prevent vitamin A deficiency in pregnant mothers, and also prevent blindness in children (Low et al., 2007). The objectives of this study was to determine the extent variation in dry matter, starch and beta-carotene in some genotypes of orange fleshed sweetpotato.

\section{MATERIALS AND METHODS}

\section{Experimental site and field layout}

The study was conducted at the University of Uyo Teaching and Research Farm in Uyo, Akwa Ibom State, Nigeria during 2020 and 2021 cropping seasons. Uyo is located in the south-south part of Nigeria and is situated within the humid tropical rainforest zone. The area lies within latitude $4^{\circ} 33^{\prime}$ and $5^{\circ} 33^{\prime}$ North and longitude $7^{\circ} 55^{\prime}$ and $8^{\circ} 25^{\prime}$ East of the Greenwich meridian. The mean annual rainfall ranges from $2680.8-2700.1 \mathrm{~mm}$ with a mean monthly relative humidity of $79.8 \%$ while the mean monthly atmospheric temperature range is $26.88-27.00^{\circ} \mathrm{C}$ (Ndaeyo, 2003). The field experiment was laid out in a randomized complete block design (RCBD) with three replications per treatment. Each replication was marked out into plots of $6 \mathrm{~m}^{2}(2 \mathrm{~m} \mathrm{x}$ $3 \mathrm{~m})$. There were six (6) plots per block and the total land size of $112 \mathrm{~m}^{2}$.

\section{Planting materials}

The planting materials (treatments) were six (6) orangefleshed sweetpotato genotypes vine cuttings obtained from National Root Crops Research Institute (NRCRI), Umudike, Abia State, Nigeria. The orange-fleshed sweetpotato genotypes were Naspot-12, Umuspo-1, Lourdes, Erica, Delvia and Umuspo-3.

\section{Agronomic practices}

The land was mechanically ploughed, harrowed and ridged $1 \mathrm{~m}$ apart. The plots were marked out using measuring tape, pegs and ropes. Sweetpotato vines were cut $25 \mathrm{~cm}$ long with four nodes. The vine cuttings were sown $30 \mathrm{~cm}$ intra-row and $100 \mathrm{~cm}$ inter-row on the crest of ridges, and $10 \mathrm{~cm}$ below the soil surface on raised beds. Poultry manure was incorporated at a recommended rate of $8.6 \mathrm{t} / \mathrm{ha}$ two weeks before planting (County, 1996). Soils with low fertility status would be improved by the application organic manure (poultry dung) into the soil during land preparation for sweetpotato production (Saviour et al., 2013). Planting was done on $21^{\text {st }}$ May, 2020 and $21^{\text {st }}$ May, 2021, using 10 vines per plot. Weeding was done at 4,8 and 12 weeks after planting (WAP). Fertilizer (NPK: 15:15:15) was applied $400 \mathrm{~kg} / /$ ha 4 weeks after planting (WAP), immediately after first weeding (Nwankwo et al., 2012). Six plants per plot were randomly selected and tagged for data collection. Harvesting was done 120 days after planting (DAP). Each plots were harvested by uprooting six plants from the middle of each plot. Vines were first cut with cutlasses and the storage roots were uprooted with fork. Data collected include; number of marketable root, number of unmarketable root, weight of marketable root, weight of unmarketable root and fresh storage root yield.

\section{Statistical analysis}

Data were taken on the following characters; number of marketable, non-marketable tubers per plot, marketable root weight $(\mathrm{kg} / \mathrm{ha})$, unmarketable root weight $(\mathrm{kg} / \mathrm{ha})$ and fresh tuber yield (t/ha). Harvest data were collected and introduced into Statistical Package for Social Scientists (SPSS) software (Version 22) for analysis of variance (ANOVA) and mean separation the means were compared by Duncan's Multiple Range Test (DMRT). Pearson's correlation analysis was done to show association among yield and yield related components of sweetpotato genotypes. Principal component analysis was done for the yield related traits. 


\section{Dry matter determination}

Dry matter content was determined within twenty-four (24) hours after harvest, two medium sized fresh storage roots per genotypes was sliced into small pieces and $100 \mathrm{~g}$ of each tuber samples was dried in hot air oven at $80^{\circ} \mathrm{C}$ for 24 hours until a constant mass was attained. Dry matter content was determined by weighing the initial and final weight, and calculating the percentage of dried weight. The same procedures were followed for all the replications. Dry matter $(\%)=$ Dry weight of the tuber/ Fresh weight of the tuber x 100

\section{Determination of starch content}

Starch content was determined based on dry matter content of storage roots. Using a dry weight conversion method, dry matter was measured by the percentage of dry weight to the fresh weight of the storage roots. The conversion formula of the starch content in sweetpotato described by

Wang, et al. (1989) was followed, i.e., $\mathrm{y}=0.86945 \mathrm{x}-$ 6.34587 , in which $\mathrm{y}$ is the starch content and $\mathrm{x}$ is the dry matter content.

\section{Determination of Beta-carotene}

Beta-carotene value was recorded as per the RHS colour chart developed by Burgos, et al. (2009) from CIP, Lima, Peru.

\section{RESULTS AND DISCUSSION}

\section{Number of marketable and unmarketable roots among six OFSP genotypes}

The result of this study showed that the six OFSP genotypes differ significantly $(\mathrm{P} \leq 0.05)$ in the number of marketable roots per plot in 2020 and 2021 cropping seasons (Table 1). The highest mean number of marketable root per plot (34.78, 32.85) was recorded in Umuspo-3, followed by Erica $(22.33,21.62)$ and Lourdes $(19.62,18.51)$ in 2020 and 2021 cropping seasons, respectively. The lowest mean number of marketable roots per plot $(6.64,6.14)$ were recorded by Delvia in both 2020 and 2021 cropping season, respectively (Table 1). The result of this study presented in Table 1 showed that the six OFSP genotypes do not differ significantly $(\mathrm{P} \leq 0.05)$ in the number of unmarketable roots per plot in 2020 and 2021 cropping seasons (Table 2). The highest mean number of unmarketable root per plot (7.33, 6.33) was recorded in Delvia, followed by Naspot-12 (6.67, 5.66) and Erica $(6.00,5.33)$ in 2020 and 2021 cropping seasons, respectively. The lowest mean number of unmarketable roots per plot $(5.33,4.66)$ were recorded by Umuspo-3 in both 2020 and 2021 cropping season, respectively (Table 1). The difference perceived among the OFSP genotypes in number of marketable and unmarketable roots per plot could be attributed to the differences in their genotypic composition. Umuspo-3 had the highest number of marketable roots per plant and this is a strong index for selection of sweetpotato to the study area (Nwankwo et al., 2012).

\section{Weight of marketable roots and unmarketable roots} among six OFSP genotypes

The result of this study showed that the six OFSP genotypes differ significantly $(\mathrm{P} \leq 0.05)$ in the weight of marketable roots per plot in 2020 and 2021 cropping seasons (Table 1). The highest mean of weight of marketable root per plot (17.27 kg/ha, $16.07 \mathrm{~kg} / \mathrm{ha})$ was recorded in Umuspo-3, followed by Umuspo-1 (10.40 kg/ha, $9.73 \mathrm{~kg} / \mathrm{ha})$ and Erica $(19.62 \mathrm{~kg} / \mathrm{ha}, 18.51 \mathrm{~kg} / \mathrm{ha})$ in 2020 and 2021 cropping seasons, respectively. The result of this study presented in Table 1 showed that the six OFSP genotypes do not differ significantly $(\mathrm{P} \leq 0.05)$ in the number of unmarketable roots per plot in 2020 and 2021 cropping seasons (Table 1). The highest weight of unmarketable roots per plot was recorded in Delvia $(2.30 \mathrm{~kg} / \mathrm{ha}, 2.26 \mathrm{~kg} / \mathrm{ha})$ in both 2020 and 2021 cropping season, respectively while the lowest weight of unmarketable roots per plot was recorded by The highest mean number of unmarketable root per plot was recorded in Naspot-12 (1.60 kg/ha, $1.50 \mathrm{~kg} / \mathrm{ha})$ in both 2020 and 2021 cropping season, respectively (Table 1).

\section{Fresh storage root yield among six OFSP genotypes}

The result of this study showed presented in Table 1 showed fresh storage root yield differed significantly $(\mathrm{P} \leq 0.05)$ in 2020 and 2021 cropping seasons. Umuspo-3 produced the highest storage root yield (28.78 t/ha, $27.59 \mathrm{t} / \mathrm{ha})$ in both 2020 and 2021 cropping seasons, respectively, followed by Umuspo-1 (17.33 t/ha, $16.67 \mathrm{t} / \mathrm{ha})$ and Erica (14.22 t/ha, $13.62 \mathrm{t} / \mathrm{ha}$ ) (Table 1). The results further showed that the genotypes Delvia produced the least fresh storage root yield (6.17t/ha, 5.50t/ha) in 2020 and 2021 cropping seasons, respectively (Table 1). The results of this study in 2020 and 2021 cropping seasons showed that two genotypes out of the five OFSP genotypes evaluated produced tuber yields higher than the world average of 15.9t/ha (FAOSTAT, 2015) namely, Umuspo-3 (28.78 t/ha, 27.59 t/ha) and Umuspo-1 (17.33 t/ha, $16.67 \mathrm{t} / \mathrm{ha})$.

Crop yield is an important quantitative as well as agronomic trait that is strongly subjective to genotypic and environmental factor factors (Njoku et al., 2009). The current result agrees with the findings of Andrade et al. (2009), who reported that the total storage root yields of five sweetpotato varieties from Sub-Saharan Africa ranged between 0.5 and $65 \mathrm{t} / \mathrm{ha}$. Following the yield classification criteria of the National Agricultural Research Organization (NARO), sweetpotato can be categorized into three fresh storage root yield classes: high-yielding (18-30 t/ha), 
moderate-yielding (11-17 t/ha) and low-yielding genotypes (below 11 t/ha) (Nwankwo et al., 2014). Based on this yield classification classes, Umuspo-3 which produced the highest yield belonged to the high-yielding class, while Umuspo-1, Erica, Naspot-12 fell to the moderate-yielding. Delvia and Lourdes were designated as low-yielding genotypes because both genotypes yielded below $11 \mathrm{t} / \mathrm{ha}$. Variability in yield has been attributed to genotypic differences as reported in some sweetpotato research (Kathabwalika et al., 2013). This result is in line with Amare et al. (2015), who also found significant differences in total tuberous root yield among varieties in their trial.
Similarly, Wariboko and Ogidi (2014) also concluded that improved orange fleshed sweetpotato varieties were higher in total tuberous root yield. However, the result of this study strongly disagreed with the findings of Bassey (2017), who reported that Umuspo-3 was generally vegetative and unproductive sweetpotato genotype. In this study, Umuspo3 recorded the highest fresh storage root yield. The superior performance of Umuspo-3 in this study could be attributed to the enrichment of low soil nutrients status by incorporation of organic manure (poultry dung) before planting sweetpotato.

Table 1: Mean values for yield and yield related characters of six OFSP genotypes in 2020 and 2021 cropping seasons

\begin{tabular}{|c|c|c|c|c|c|c|c|c|c|c|}
\hline \multirow[t]{2}{*}{ Genotypes } & \multicolumn{2}{|c|}{ NMR } & \multicolumn{2}{|c|}{ NUR } & \multicolumn{2}{|c|}{ WMR (kg/ha) } & \multicolumn{2}{|c|}{ WUR (kg/ha) } & \multicolumn{2}{|c|}{ Yield (t/ha) } \\
\hline & 2020 & 2021 & 2020 & 2021 & 2020 & 2021 & 2020 & 2021 & 2020 & 2021 \\
\hline Nasp & $16.95 \pm 1.84^{\mathrm{c}}$ & $.07 \pm 1.10^{\mathrm{c}}$ & $57 \pm 2.51^{\mathrm{a}}$ & $5.66 \pm 1.52^{\mathrm{a}}$ & $8.00 \pm 1.00^{\mathrm{b}}$ & $7.50 \pm 0.50^{\mathrm{c}}$ & $1.60 \pm 0.36^{\mathrm{a}}$ & $1.50 \pm 0.50^{\mathrm{a}}$ & $13.33 \pm 1.66^{\mathrm{b}}$ & $12.67 \pm 0.88^{\mathrm{c}}$ \\
\hline Umu & $17.33 \pm 1.19^{c}$ & $16.22 \pm 1.34^{\mathrm{c}}$ & $6.00 \pm 2.64^{\mathrm{a}}$ & $5.00 \pm 1.00^{\mathrm{a}}$ & $10.40 \pm 0.96^{\mathrm{b}}$ & $9.73 \pm 0.25^{\mathrm{b}}$ & $2.13 \pm 0.64^{\mathrm{a}}$ & $2.00 \pm 0.60^{\mathrm{a}}$ & $17.33 \pm 1.60^{\mathrm{b}}$ & $16.67 \pm 0.50^{\mathrm{b}}$ \\
\hline Lourdes & $19.62 \pm 1.66^{\mathrm{bc}}$ & $18.51 \pm 0.88^{b c}$ & $4.67 \pm 3.05^{\mathrm{a}}$ & $3.66 \pm 1.53^{\mathrm{a}}$ & $5.33 \pm 1.16^{\mathrm{c}}$ & $5.00 \pm 0.65^{\mathrm{d}}$ & $1.93 \pm 0.50^{\mathrm{a}}$ & $1.79 \pm 0.34^{\mathrm{a}}$ & $8.89 \pm 1.94^{\mathrm{c}}$ & $8.22 \pm 0.94^{\mathrm{d}}$ \\
\hline Erica & $22.33 \pm 1.52^{\mathrm{b}}$ & $21.62 \pm 0.54^{\mathrm{b}}$ & $6.00 \pm 2.64^{\mathrm{a}}$ & $5.33 \pm 1.53^{\mathrm{a}}$ & $8.53 \pm 1.30^{\mathrm{b}}$ & $7.87 \pm 0.70^{\mathrm{bc}}$ & $2.07 \pm 0.50^{\mathrm{a}}$ & $1.95 \pm 0.32^{\mathrm{a}}$ & $14.22 \pm 2.16^{\mathrm{b}}$ & $13.62 \pm 1.40^{\mathrm{c}}$ \\
\hline Delvia & $6.64 \pm 0.66^{\mathrm{d}}$ & $6.14 \pm 1.46^{\mathrm{d}}$ & $7.33 \pm 3.05^{\mathrm{a}}$ & $6.33 \pm 2.08^{\mathrm{a}}$ & $3.70 \pm 1.47^{\mathrm{c}}$ & $3.37 \pm 1.48^{\mathrm{d}}$ & $2.30 \pm 0.50^{\mathrm{a}}$ & $2.26 \pm 0.43^{\mathrm{a}}$ & $6.17 \pm 2.45^{\mathrm{c}}$ & $5.50 \pm 1.73^{\mathrm{d}}$ \\
\hline Umuspo-3 & $34.78 \pm 3.23^{\mathrm{a}}$ & $32.85 \pm 6.14^{\mathrm{a}}$ & $5.33 \pm 2.30^{\mathrm{a}}$ & $4.66 \pm 1.15^{\mathrm{a}}$ & $17.27 \pm 2.03^{\mathrm{a}}$ & $16.07 \pm 2.01^{\mathrm{a}}$ & $2.17 \pm 0.76^{\mathrm{a}}$ & $2.02 \pm 0.52^{\mathrm{a}}$ & $28.78 \pm 3.38^{\mathrm{a}}$ & $27.55 \pm 1.27^{\mathrm{a}}$ \\
\hline
\end{tabular}

Values with the same letter(s) across each column do not differ significantly $(\mathrm{p} \leq 0.05)$.

NMR $=$ Number of marketable roots, NUR $=$ Number of unmarketable roots $(\mathrm{kg} / \mathrm{ha}), \mathrm{WMR}=$ Weight of marketable roots $(\mathrm{kg} / \mathrm{ha})$, WUR = Weight of unmarketable roots $(\mathrm{kg} / \mathrm{ha})$.

\section{Dry matter content}

Table 2 showed the dry matter content of the six orangefleshed sweetpotato genotypes cultivated in 2020. Umuspo3 recorded the highest dry matter content of $42.78 \%$, followed by Lourdes and Erica with dry matter content of $40.60 \%$ and $40.10 \%$, respectively. The lowest dry matter content of $31 \%$ was observed in the Umuspo-1. Nwankwo and Afuape (2013) reported that dry matter content of $27 \%$ and above has been considered acceptable to most processors of sweetpotatoes. All the OFSP genotypes evaluated in this study recorded dry matter content of $27 \%$ and above (Table 2). High dry matter content is one of the major aims in sweetpotato breeding programs. Dry matter content differs due to factors such as variety, location, climate, incidence of pests and diseases, cultural practices and soil types (Vimala and Hariprakash, 2011).

\section{Starch content}

The result presented in Table 2 showed that dry matter and starch contents differ significantly $(\mathrm{P} \leq 0.05)$. The starch content ranged from $24.55 \mathrm{mg} 100 \mathrm{~g}^{-1}$ to $65.23 \mathrm{mg} 100^{-1}$. Lourdes had the highest starch content, $65.23 \mathrm{mg} 100 \mathrm{~g}^{-1}$ while Umuspo-3 had the lowest starch content, $24.55 \mathrm{mg} 100^{-1}$. Among the six OFSP genotypes evaluated, five (5) genotypes; Naspot-12 (57.28 mg100 $\left.{ }^{-1}\right)$, Umuspo-1 $\left(58.53 \mathrm{mg}^{100^{-1}}\right)$, Lourdes $\left(62.53 \mathrm{mg} 100^{-1}\right)$, Erica $(65.23$ $\left.\mathrm{mg} 100^{-1}\right)$ and Delvia $\left(5.73 \mathrm{mg} 100^{-1}\right)$ recorded starch content above $50 \mathrm{mg} \mathrm{100}^{-1}$. Nwankwo et al., (2014) reported that dry matter content has been reported to be related to starch content in sweetpotato. The result of this study indicates that the six OFSP genotypes evaluated could be used for industrial processing.

\section{Beta-carotene content}

The Beta-carotene content in sweetpotato was recorded using RHS colour chart of CIP. According to the RHS colour chart, Beta-carotene content of the six OFSP genotypes ranged from $1.03 \mathrm{mg} / 100 \mathrm{~g}$ FW to $9.19 \mathrm{mg} / 100 \mathrm{~g}$ FW. Umuspo-3 recorded a Beta-carotene content of 9.19 $\mathrm{mg} / 100 \mathrm{~g} \mathrm{FW}$ and Lourdes had very low Beta-carotene in the tuber $(1.03 \mathrm{mg} / 100 \mathrm{~g} \mathrm{FW})$ (Table 2). The six OFSP genotypes could be grouped into three categories based on their beta-carotene content; Deep orange (4.29 - 18.55 $\mathrm{mg} / 100 \mathrm{~g} \mathrm{FW})$, Intermediate orange $(2.08-8.36 \mathrm{mg} / 100 \mathrm{~g}$ $\mathrm{FW})$ and Pale orange (0.56 - $4.47 \mathrm{mg} / 100 \mathrm{~g} \mathrm{FW})$. OFSP is beneficial in enhancing vitamin A intake. OFSP, carrots and leafy vegetables are enriched with high levels of $\beta$-carotene (Ingabire and Vasanthakaalam, 2011). Umuspo-3 OFSP 
with the highest $\beta$-carotene content in this study could be recommended as a source of $\beta$-carotene to address vitamin
A deficiency especially in young children and pregnant women.

Table 2: Mean value for dry matter, starch, beta-carotene of six OFSP genotypes

\begin{tabular}{|c|c|c|c|c|}
\hline Genotypes & Dry matter & Starch & $\begin{array}{l}\text { Beta-carotene } \\
(\mathrm{mg} / 100 \mathrm{~g} F W)\end{array}$ & Beta-carotene group \\
\hline Naspot-12 & $33.80 \pm 1.01^{\mathrm{d}}$ & $57.28 \pm 2.01^{b}$ & 8.02 & Intermediate orange \\
\hline Umuspo-1 & $31.00 \pm 1.41^{\mathrm{e}}$ & $58.53 \pm 2.51^{\mathrm{a}}$ & 4.19 & Pale orange \\
\hline Lourdes & $40.60 \pm 1.52^{\mathrm{b}}$ & $62.53 \pm 2.32^{\mathrm{a}}$ & 1.03 & Pale orange \\
\hline Erica & $40.10 \pm 1.23^{\mathrm{b}}$ & $65.23 \pm 2.71^{\mathrm{a}}$ & 1.63 & Pale orange \\
\hline Delvia & $39.00 \pm 1.11^{\mathrm{bc}}$ & $55.73 \pm 2.51^{b}$ & 4.23 & Pale orange \\
\hline Umuspo-3 & $42.78 \pm 1.31^{\mathrm{a}}$ & $24.55 \pm 2.51^{\mathrm{c}}$ & 9.19 & Deep orange \\
\hline
\end{tabular}

Values with the same letter(s) across each column do not differ significantly $(\mathrm{p} \leq 0.05)$.

Table 3 showed the Pearson correlation co-efficients $(\gamma)$ for the storage root parameters for six OFSP genotypes. Total storage root yield had significant and positive correlation coefficient with number of marketable roots and marketable weight per plot but had a negative correlation coefficient with number of unmarketable roots (Table 3). Correlation coefficients for the 7 traits are presented in Table 3 . Generally, all the traits except unmarketable storage root weight exhibited positive and significant $(\mathrm{P}<0.05$ and $\mathrm{P}<0.01)$ correlation with yield. Some of the traits also exhibited significant and positive association among themselves as well as significant and negative association. Yield at harvest had a positive association with unmarketable fresh storage root number $(r=0.02)$ (Table 3 ). Yield at harvest, however, had a positive association with unmarketable fresh storage root weight $(r=-0.40)$. Yield at harvest had a negative association with dry matter $(\mathrm{r}=-0.036)$ and starch $(\mathrm{r}=-0.034)$ (Table 3). In line with the current study, Stathers et al, (2003) and Islam et al. (2002) showed that vine length and number of roots were positively and significantly correlated with root yield (total root weight). Tsegaye et al., (2006) reported positive yet significant root girth among thirty sweetpotato genotypes. Selection of correlated traits influences each other thus allowing simultaneous selection in plant breeding programmes (Rukundo et al, 2013). Similarly, Yohhanes et al., (2010) reported that total storage root yield had significant and positive association with marketable storage root yield and average storage root weight. Gunjan (2012) also reported that marketable tuberous root yield was positively correlated with total tuberous root yield. This indicates that yield is an important agronomic index which shows adaptability of a genotype to its growing environment (Antiaobong and Bassey, 2008) and hence genotype Umuspo-3 can be identified as the highest tuberous root yielding and adaptable genotype to the study area and also number of marketable roots and marketable root weight can be used as important factors for selection of sweetpotato to growers aimed at producing sweetpotatoes for tuber production and serves as an indicator of adaptability of the crop to the local growing conditions (Nwankwo et al., 2012).

\section{Principal component analyses}

Two main principal component axes (PC1 and PC2) in the principal component analysis (PC analysis had eigen values up to 1.0 , presenting cumulative variance of $70.25 \%$ (Table 4). Principal component one (PC1), with eigen value of 3.71 , contributed $53.11 \%$ of the total variability, while $\mathrm{PC} 2$, with eigen value of 1.19 , accounted for $17.13 \%$ of total variability observed among the six OFSP genotypes. In PC1, the traits that accounted for most of the $53.11 \%$ observed variability among the six OFSP included number of marketable roots, with vector loading of 0.915 , weight of marketable roots (0.956), yield (0.943), dry matter and starch contents ( 0.476 and -0.861 , respectively) (Table 4). Four main components (PC) were identified, accounting for $67.22 \%$ of the total variation between accessions (Koussao et al., 2014). Placide et al., (2015) also used PCA to study the variability between 54 sweetpotato genotypes and found the cumulative variance of $77.83 \%$ from the first seven major component axes. 
Table 3: Correlation of yield and yield related characters of six OFSP genotypes in 2020 and 2021 cropping seasons

\begin{tabular}{llllllll}
\hline & NMR & NUR & WMR & WUR & Yield & Dry matter & Starch \\
\hline NMR & & & & & & \\
NUR & -0.327 & & & & & \\
WMR & $0.877^{* *}$ & -0.227 & & & & \\
WUR & 0.087 & -0.408 & 0.199 & & & \\
Yield & $0.877^{* *}$ & -0.227 & $0.997^{* *}$ & 0.199 & & \\
Dry matter & 0.412 & -0.201 & 0.196 & 0.138 & 0.196 & \\
Starch & $-0.664^{* * *}$ & -0.022 & $-0.762^{* *}$ & -0.053 & $-0.762^{* *}$ & $-0.491^{*}$ & \\
\hline
\end{tabular}

**. Correlation is significant at the 0.01 level (2-tailed).

*. Correlation is significant at the 0.05 level (2-tailed).

NMR = Number of marketable roots, NUR = Number of unmarketable roots $(\mathrm{kg} / \mathrm{ha})$,

WMR = Weight of marketable roots $(\mathrm{kg} / \mathrm{ha})$, WUR $=$ Weight of unmarketable roots $(\mathrm{kg} / \mathrm{ha})$.

Table 4: Principal component analysis of six OFSP genotypes in 2020 and 2021 cropping seasons

\begin{tabular}{lll}
\hline & PCA 1 & \\
& 0.915 & PCA 2 \\
\hline NMR & -0.310 & 0.018 \\
NUR & 0.956 & -0.709 \\
WMR & 0.116 & -0.199 \\
WUR & 0.943 & 0.550 \\
Yield (t/ha) & 0.476 & -0.211 \\
Dry matter & -0.861 & 0.525 \\
Starch & 3.718 & 0.187 \\
Total & 53.118 & 1.199 \\
\% of Variance & 53.118 & 17.136 \\
Cumulative \% & & 70.253 \\
\hline
\end{tabular}

\section{CONCLUSION}

This study showed that the six orange-fleshed genotypes differed significantly for fresh storage root yield, dry matter, starch and beta-carotene content. In this present study, two OFSP genotypes; Umuspo-3 and Umuspo-1(28.78t/ha and $17.33 \mathrm{t} / \mathrm{ha}$ ) produced highest fresh storage roots yield, respectively, above the world's average yield of sweetpotato $(15.9 \mathrm{t} / \mathrm{ha})$ and could recommended for production in Uyo agro-ecology. Umuspo-3 showed high dry matter (42.78\%) and Beta-carotene content (9.19 $\mathrm{mg} / 100 \mathrm{~g} \mathrm{FW})$. Umuspo-3 is sweetpotato genotype enriched with carotenoid and could be cultivated in Uyo agroecology as an excellent source of beta-carotene to ameliorate vitamin A deficiency in children and pregnancy women within the State and its environs.

\section{DECLARATION OF CONFLICTING INTERESTS}

The authors declared no potential conflicts of interest with respect to the research, authorship, and/or publication of this article.

\section{REFERNCES}

[1] Amare, B., Abay, F. \& Tsehaye, Y. (2015). Evaluation of sweet potato (Ipomea batata I.) Varieties for Total Storage 
Root Yield in South East Zones of Tigray, Ethiopia. American Journal of Trade and policy 1(2): 74-78.

[2] Andrade, E.K.V., Carvalho de Andrade Junior V., Luiz de Laia, M., Cunha Fernandes, J. S., Oliveira A. J. M. \& Azevedo. A.M. (2017). Genetic dissimilarity among sweet potato genotypes using morphological and molecular descriptors. Acta Scientiarum Agronomy 39:447-455.

[3] Antiaobong, E.E. and E.E. Bassey, (2008). Constraints and prospects of sweet potato (Ipomoea batatas L.) production in humid environment of southeastern Nigeria. Proceedings of the second african regional conference on sustainable agriculture, (SARCSA'08), Governor's office Annex, Uyo, Nigeria, pp: 68-72.

[4] Bassey, E. E. (2017). Variability in the yield and character association in Nigerian sweet potato (Ipomoea batatas (L.) Lam) genotypes. African journal of crop science. 5 (5): 001 009

[5] Burgos, G., Carpio, R, Sanchez, C, Sosa, P, Porras, E, Espinoza, J. and Gruneberg, W. (2009). Guide for using the RHS colour chart for selecting for high Beta-carotene sweet potato. 30p.

[6] County, V. (1996). Poultry manure as a source of nitrogen in potato production: part I. Agriculture and Aquaculture, Abstract.

[7] FAO (2015). Food and Agriculture Organisation of the United Nations-Crop Production Statistics. Available: http://faostat.fao.org/.

[8] Food and Agriculture Organization Statistics (FAOSTAT) (2015). http://faostat.fao.org/site/291/default.aspx

[9] Gunjan, J., (2012). Increasing productivity of sweet potato, Ipomoea batatas (L.) Lam through clonal selection of ideal genotypes from open pollinated seedling population. International Journal of Farm Sciences 2: 17-27.

[10] Ingabire MR and Vasanthakaalam H (2011). Comparison of the Nutrient composition of four sweet potato varieties cultivated in Rwanda. American Journal of Food and Nutrition, 1: 34-38.

[11] Kathabwalika, D.M., Chilembwe, E.H.C., Mwale, V.M., Kambewa, D. \& Njoloma, J.P. (2013). Plant growth and yield stability of orange fleshed sweet potato (Ipomoea batatas) genotypes in three agro-ecological zones of Malawi. Int. Res. J. Agric. Sci, Soil Sci., 3(11): 383-392.

[12] Koussao, S., Gracen, V., Asante, I., Danquah, E. Y., Ouedraogo, J. T., Baptiste, T. J., Jerome, B., \& Vianney, T. M (2014). Diversity analysis of sweet potato (Ipomoea batatas [L.] Lam) germplasm from Burkina Faso using morphological and simple sequence repeats markers. African Journal of Biotechnology, 13(6), 729-742.

[13] Low, J. W., Arimond, M., Osman, N., Cunguara, B., Zano, F., \& Tschirley, D. (2007). A food-based approach introducing orangefleshed sweet potatoes increased vitamin A intake and serum retinol concentrations in young children in rural Mozambique. Journal of Nutrition Community and International Nutrition, 137, 1320-1327.

[14] Mukhtar A.A., Tanimu B., Arunah U.L. \& Babaji B.A. (2010). Evaluation of Agronomic Characters of Sweet potato varieties grown at varying levels of organic and inorganic fertilizers. World Journal of Agricultural Science 6(4):370373.

[15] Mwanga, R.O.M., Odongo, B., Niringiye, C., Alajo, A., Abidin, P.E., Kapinga, R., Tumwegamire, S., Lemaga, B., Nsumba, J. and Carey, E.E. (2007). Release of two orangefleshed sweetpotato cultivars, 'SPK004' ('Kakamega') and 'Ejumula' in Uganda. Hortscience 42(7).

[16] Ndaeyo, N.U., (2003). Growth and yield of maize (Zea mays L.), cassava (Manihot esculenta Crantz) as influenced by different tillage practices. Journal of Sustainability Tropical Agricultural Research, 8(1): $82-88$

[17] Njoku, J. C., Muoneke, C. O., Okocha, P. I., \& Ekeleme, F. (2009). Effect of propagule size and intra-row spacing on the growth and yield of sweet potato in humid agro-ecological zone. The Nigerian Agricultural Journal, 40 (1 and 2), 115124.

[18] Nwankwo, I.I.M. and Afuape, S. O. (2013) of High Altitude Orange-Fleshed Sweet (Ipomoea batatas) Genotypes For Yield in Lowland Rainforest Ecology of Umudike Southeastern Nigeria. IOSR Journal of Agriculture and Veterinary Science, 5(6): 77-81.

[19] Nwankwo, I.I.M., Bassey, E.E., Afuape, S.O., Njoku, J., Korieocha, D.S., Nwaigwe G. and Echendu, T.N.C. (2012). Morpho-agronomic characterization and evaluation of incountry sweet potato accessions in southeastern Nigeria. Journal of Agricultural Science 4: 281-288.

[20] Nwankwo, I.I.M., E.E. Bassey and S.O. Afuape, (2014). Yield Evaluation of Open-Pollinated Sweet Potato (Ipomoea batatas (L.) Lam.) Genotypes in Humid Environment of Umudike, Nigeria. Global of Biology, Agriculture and Health Sciences, 3(1): 199-204.

[21] Omiat, E.G., R.E. Kapinga, S. Tumwegamire, T.L. Odong \& E. Adipala, 2005. On-farm evaluation of orange-fleshed sweetpotato varieties in Northeastern Uganda. Afr. Crop Sci. Conf. Proc., 7: 603-609.

[22] Placide, R., Shimelis, H. Laing, M. \& Gahakwa, D. (2015). Phenotypic characterization of sweetpotato genotypes grown in East and Central Africa. South African Journal of Plant and Soil 32:77-86

[23] Rahman, S. M. M., Wheatley, C., Rakshit, S. K. (2003). Selection of sweet potato variety for high starch extraction. Int. J. Food Propert., 6 (3): 419-430

[24] Rukundo P., Hussein S., Mark L., \& Daphrose G. (2013). Phenotypic characterization of sweetpotato genotypes grown in East and Central Africa. South African J. Plant and Soil. 32:77-86.

[25] Saviour, O. N., Okon, D. P. \& Roberts, S. P. (2013). Comparative effects of chicken manure and NPK on the yield of Ipomoea batatas Journal of Agricultural and Crop Research (6), pp. 90-93.

[26] Singh, S., C. S. Riar and D. C. Saxena (2008). Effect of incorporating sweet potato flour to wheat flour on the quliaty characteristics of cookies. Agri. J. Food Sci. 2:065-072.

[27] Tsegaye E., Devakara Sastry E.V. and Dechassa N. (2006). Correlation and path analysis in sweetpotato and their implications for clonal selection. Journal of Agronomy 5 (3): 391-395. 
[28] Tumwegamire, S., Kapinga, R., Rubaihayo, P.R. et al. (2011). Starch, sucrose, b-carotene, iron, zinc, calcium, and magnesium in East African sweetpotato [Ipomoea batatas (L.) Lam.] germplasm. Horticultural Science, 46, 348-357.

[29] Vimala, B. and Hariprakash, B. 2011. Variability of morphological characters and dry matter content in the hybrid progenies of sweet potato (Ipomoea batatas (L) Lam). Gene Conserve. 10: 65-86.

[30] Wang. S. S., Chiang, W. C, Yeh, A. 1.. Zhao. B., and Kim, I. H. (1989). Kinetics of phase transition of waxy com starch at extrusion temperatures and moisture contents. J. Food Sci. 54: 1298-130 I

[31] Wariboko C, Ogidi IA. 2014. Evaluation of the performance of improved sweetpotato (Ipomoea batatas L. LAM) varieties in Bayelsa State, Nigeria. African J Environ Sci Technol 8 (1): 48-53.

[32] Willcox DC, Willcox BJ, Todoriki H, Suzuki M. (2009).The Okinawan diet: health implications of a low-calorie, nutrientdense, antioxidant-rich dietary pattern low in glycemic load. J. Am. Coll. Nutr.28(Suppl):500S-516S.

[33] Yohannes G., Getachew B. \& Nigussie D. (2010). Genotypic and Phenotypic Correlations of Root Yield and other Traits of Orange-Fleshed Sweetpotatoes [Ipomoea batatas (L.) Lam.]. Journal of the Dry lands 3(2): 208-213. 